\title{
Acute Effects of Smoking on Heart Rate and Peripheral Resistance in Young Smokers
}

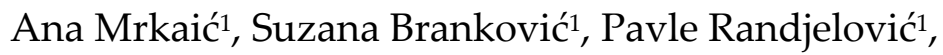 \\ Milica Veljković ${ }^{1}$, Ivan Pavlović ${ }^{2}$, Mirjana Radenković ${ }^{1}$ \\ ${ }^{1}$ University of Niš, Faculty of Medicine, Department of Physiology, Niš, Serbia \\ ${ }^{2}$ University of Belgrade, Faculty of Pharmacy, Department of Pharmacognosy, Belgrade, Serbia
}

\section{SUMMARY}

Smoking has many harmful effects on human body. It is well known that smoking is one of the most important risk factors for cardiovascular diseases. Though the ingredients from cigarette smoke stimulate the release of vasoconstrictor and reduce the release of vasodilator substances, the goal of this study was to investigate the acute effects of smoking on arterial blood pressure, heart rate and blood vessel flow.

The investigation was conducted on forty healthy volunteers divided into two groups of twenty non-smokers (control group), and twenty smokers (experimental group). The group of smokers was examined before and after smoking four cigarettes during one hour. Blood pressure and electrocardiograph (ECG) were measured by common methods. Brecht's and Boucke's methods of plethysmography were used to evaluate the peripheral circulation.

There were no differences in measured systolic and diastolic blood pressure and recorded ECG between non-smokers and smokers, neither between smokers before and after smoking. However, heart rate was increased by $\mathbf{2 9 . 5 7 \%}$ after smoking in comparison to the value before smoking.

Evaluation of plethysmographic parameters showed that amplitude was significantly decreased. Parameters of peripheral resistance were very increased: ductility was decreased by over $20 \%$.

It can be concluded that acute smoking does not significantly affect the level of blood pressure, although it increases heart rate. The shape of plethysmograms showed decreased systolic filling and decreased diameters of blood vessels.

Key words: smoking, heart rate, ECG, plethysmography

\author{
Corresponding author: \\ Mirjana Radenković \\ email: mirjanakos@medfak.ni.ac.rs
}




\section{INTRODUCTION}

Nicotine, one of the four thousand substances from cigarette smoke, was identified back in 1800 . The usual nicotine content in one cigarette is $6-11 \mathrm{mg}$, of which men inhale 1-2 mg during smoking. Nicotine is primarily taken into the body by inhalation, but it can be also reabsorbed through the skin, mucosa of oral cavity and nose, and just ten seconds after the inhalation it can be found in the brain and all parts body of the body (1).

The inhaled cigarette smoke is promptly absorbed into the bloodstream reaching a maximum value after 5-8 minutes and starts to decrease over the next 20 minutes. The amount of nicotine that reaches bloodstrem depends on the puff volume, room ventilation, rate of puffing and the nicotine percent in saliva (2). Nicotine is mainly eliminated through the liver, and to a smaller extent through the kidney, with a half-life elimination time of two hours (3).

Smoking has numerous adverse effects on human health. First of all, it attacks lungs, but also disturbs endocrine gland function, and decreases growth hormone, cortisol, testosterone and insulin concentrations in blood $(4,5)$. It also interferes with the function of CNS, cardiovascular and other systems.

Smoking was for the first time related to cardiovascular system diseases back in 1940. Nowadays, it is a well-known fact that smoking is one of the strongest risk factors for cardiovascular diseases, including coronary artery disease, cardiac arrest, peripheral artery disease, aortic aneurysm and cerebrovascular insult (6). Some earlier studies have suggested that smoking a cigarette elevates both blood pressure and heart rate, and it is associated with higher norepinephrine and epinephrine levels in the plasma (7). It was later confirmed that smoking increased sympathetic outflow to the heart and other tissues, including skeletal muscles in humans (8). In clinical studies, it has been shown that light cigarette smoking has similar acute detrimental effects on coronary microvascular function as does regular cigarette smoking (9). Many authors verified the substantial and immediate beneficial effects of smoking cessation on cardiovascular system (10). Passive smoking is also associated with the development of atherosclerosis, coronary artery disease and stroke, and recently has been blamed for vascular endothelial dysfunction in a lot of studies. It has also been related to ischemic heart disease and dysfunction of the left ventricle. Besides, passive smoking increases the values of systolic pressure and heart rate (11).

In contrast to experimental findings, in clinical ones there are no significant differences in the values of blood pressure and heart rate between smokers and non-smokers. Minor differences have been detected in the older population of smokers, whose daily pressure was slightly higher compared to non-smokers, while nocturnal pressures did not differ (12).

Since we could find in the literature mainly the data about chronic effects of smoking on health, we enquired if acute smoking has any effects. Therefore, the aim of our research was to study the acute effects of smoking on blood pressure, heart rate and blood flow.

\section{SUBJECTS AND METHODS}

\section{Subjects}

The study was performed on healthy volunteers in accordance with ethical standards. Forty college-aged subjects (cigarette smokers $n=20$ and non-smokers $n=20$ ) participated in the study. There were 24 males and 16 females (aged 20-26, mean $23.39 \pm 3.5$ years). All of them were healthy and without any acute or chronic lung disease. Volunteers were instructed to abstain from caffeine and other known vasoconstrictor compounds for at least $24 \mathrm{~h}$ before this study.

Body weight was determined to the nearest 0.1 $\mathrm{kg}$, with height measured as well. Body mass index (BMI) was calculated as weight $(\mathrm{kg})$ divided by height (m) squared.

\section{Experimental procedure}

Plethysmograms were obtained using a photo plethysmometer (Fukuda Denshi, Japan; SDP-100). Each subject was laid comfortably supine on a bed for $5 \mathrm{~min}$ in a quiet room with a temperature of $24-25^{\circ} \mathrm{C}$ and humidity of $70-75 \%$ before recording. Plethysmography sensor (Brecht and Bouke) was applied to the index or to the middle finger of the left hand.

Plethysmography method was used for the evaluation of peripheral blood flow. Plethysmographic features such as waveform 
amplitude, width, and area under the curve were calculated. Plethysmographic wave form amplitude was measured as the vertical distance between peak and basal line and was expressed in millimeters. Pulse width was measured at half height of the beat. Mean values were taken from five consecutive cycles of each measurement.

Blood pressure, systolic and diastolic, and pulse rate were measured in the sitting position just before recording.

All the measurements were performed in the group of non-smokers, which was the control group, and in the group of smokers, which was the experimental group. After control measurements, smokers were instructed to smoke four cigarettes containing $1.2 \mathrm{mg}$ of nicotine and $14 \mathrm{mg}$ of tar, in 60 minutes, and measurements were then repeated.

\section{Statistical analysis}

Values are presented as mean \pm SD. The data were compared between smokers and non-smokers using the unpaired Student's t-test. In all analyses, a $\mathrm{p}$-value of $<0.05$ was considered to be statistically significant.

\section{RESULTS}

The investigation was conducted on forty healthy volunteers divided into two groups of twenty non-smokers (control group), and twenty smokers (experimental group). The group of smokers was examined before and after smoking four cigarettes in an hour. There were 12 males and 8 females in both groups. Their age, height, weight and BMI are shown in Table 1.

Table 1. Characteristics of smokers and control subjects

\begin{tabular}{lcccc}
\hline \hline & \multicolumn{2}{c}{ Control subjects $(\mathrm{n}=20)$} & \multicolumn{2}{c}{ Smokers $(\mathrm{n}=20)$} \\
Gender & Male & Female & Male & Female \\
Number & 12 & 8 & 12 & 8 \\
Age $(\mathrm{yrs})$ & $23.15 \pm 5.12$ & $22.89 \pm 4.63$ & $23.53 \pm 3.5$ & $24.02 \pm 6.61$ \\
Height $(\mathrm{cm})$ & $178.95 \pm 7.22$ & $169.93 \pm 5.92$ & $181.43 \pm 8.24$ & $171.01 \pm 4.82$ \\
Weight $(\mathrm{kg})$ & $72.50 \pm 8.58$ & $58.24 \pm 6.22$ & $73.76 \pm 11.42$ & $59.87 \pm 8.64$ \\
BMI $\left(\mathrm{kg} / \mathrm{m}^{2}\right)$ & $22.78 \pm 10.48$ & $20.35 \pm \backslash 7.12$ & $22.32 \pm 9.74$ & $20.54 \pm 6.95$ \\
\hline \hline
\end{tabular}

\section{Control groups}

Non-smokers. The estimated blood pressure mean values were $110 \mathrm{~mm} \mathrm{Hg}$ for systole and $77 \mathrm{~mm}$ $\mathrm{Hg}$ for diastole, while the heart rate mean value was 71 per minute in non-smokers. There were no pathological changes representing any pathology either by ECG or by plethysmography.
Smokers before smoking. The mean value of blood pressure in smokers, actually in experimental group, was $112 \mathrm{mmHg}$ for systole and $80 \mathrm{~mm} \mathrm{Hg}$ for diastole, while the heart rate mean value was 72 beats/min. ECG recorded in smokers was normal, without any pathological changes. Plethysmogram parameters in non-smokers and smokers before smoking were almost identical, without any significant difference, as proven using the t-test, which is shown in Table 2.

Table 2. Smoking effects on blood pressure and heart rate

\begin{tabular}{lccc}
\hline \hline & Control subjects $(\mathrm{n}=20)$ & $\begin{array}{c}\text { Smokers before smoking } \\
(\mathrm{n}=20)\end{array}$ & $\begin{array}{c}\text { Smokers after smoking } \\
(\mathrm{n}=20)\end{array}$ \\
Systolic BP (mmHg) & $110.54 \pm 20.36$ & $112.41 \pm 18.35$ & $116.97 \pm 19.04$ \\
Diastolic BP (mmHg) & $77.25 \pm 8.36$ & $80.27 \pm 10.54$ & $80.82 \pm 9.37$ \\
Heart rate (beat/min) & $71.23 \pm 9.58$ & $72.44 \pm 8.22$ & $92.67 \pm 10.46^{* *}$ \\
\hline \hline
\end{tabular}

${ }^{* *} p<0.01$ - significantly different from control 
Smokers after smoking. There were deviations, although not significant, in the values of the registered systolic pressure in experimental group after smoking. The mean blood pressure value in smokers after smoking was $116 \mathrm{~mm} \mathrm{Hg}$ for systolic and $80 \mathrm{~mm} \mathrm{Hg}$ for diastolic pressure, while the heart rate mean was about 92 beats/min. The heart rate was by $29.57 \%$ higher compared to pre-smoking values. ECG did not show any significant changes, comparing the values before and after smoking.

Table 3. Results of the plethysmographic parameters before and after smoking

\begin{tabular}{lccc}
\hline \hline & Control subjects & Smokers before smoking & Smokers after smoking \\
Amplitude & $18.39 \pm 2.58$ & $17.48 \pm 3.01$ & $13.54 \pm 1.89^{*}$ \\
Width & $5.19 \pm 1.30$ & $4.84 \pm 0.87$ & $4.15 \pm 0.72$ \\
Area under the curve & $120.14 \pm 14.25$ & $117.71 \pm 12.26$ & $92.93 \pm 11.54^{* *}$ \\
\hline \hline
\end{tabular}

On the other hand, in plethysmogram analyses, there was an amplitude decrease registered (shown in Table 3), while the parameters indicative of peripheral resistance were significantly increased. This meant that inotropy was not significantly changed, while ductility was decreased by more than $20 \%$. Besides, systole filling was also decreased, as much as the plethysmogram area representing blood vessel mean size.

\section{DISCUSSION}

Our results show that in chronic smokers smoking four cigarettes induces acute hemodynamic effects. There were no significant differences in arterial blood pressure between smokers and nonsmokers before smoking. Also, there were no statistically significant changes in blood pressure values after smoking $(p>0.05)$. Our results differ from the results obtained in other studies. Smoking or intravenous nicotine administration increases arterial blood pressure and heart rate in humans (12). We did not get significant blood pressure changes even after four smoked cigarettes, while in other studies blood pressure elevation immediately after the first smoked cigarette was observed (3).

This could be partly explained by the fact that the investigated people were young so their baroreceptor response is intact. Literature data have shown that while baroreflex function in older longterm smokers was impaired, it was intact in younger people (13).

On the other hand, our results indicate that heart rate significantly increases after four smoked cigarettes, which affects the plethysmogram shape. This is similar to the results of other authors who described a reduction of pulse interval and an increase in both vascular resistance and heart rate (14) after smoking. Literature data indicated that smoking changes the balance of the autonomic nervous system and increases sympathetic nerve activity (13). Plethysmogram data indicate that certain plethysmographic parameters such as amplitude, width and area under the curve are decreased. All these changed parameters indicate an increase of vascular resistance, i.e. decrease of blood vessel compliance of over $20 \%$ after smoking. This was to be expected in long-term smoking, with overt endothelial dysfunction and arterial blood vessel changes (15). Our examinees were young and healthy individuals and such a finding can be explained by an acute stimulation of the sympathetic nervous system causing heart rate increases, which subsequently reduces heart stroke volume. That is why blood pressure remains unaffected, although certain plethysmographic parameters indicate increased peripheral vascular resistance. This also corroborates the findings of many out-patient studies, stating that the impact of smoking on blood pressure is not significant.

A conclusion may be drawn from our study that acute smoking does not significantly affect the level of blood pressure, although it increases heart rate. Plethysmogram shapes showed decreased systole filling and decreased blood vessels diameter.

This work was supported by the Ministry of Education, Science and Technological Development of the Republic of Serbia (grant No. III41018). 


\section{References}

1. Dani JA, De Biasi M. Cellular mechanisms of nicotine addiction. Pharmacol Biochem Behav 2001; 4: 439-46

http://dx.doi.org/10.1016/S0091-3057(01)00652-9

2. Benowitz NL, Hukkanen J, Jacob P. Nicotine chemistry, metabolism, kinetics and biomarkers. Handb Exp Pharmacol 2009; 192: 29-60.

http://dx.doi.org/10.1007/978-3-540-69248-5_2

3. Farha KA, Farha RA, Bolt M. The acute impact of smoking one cigarette on cardiac hemodynamic parameters. Cardiol Res 2011; 2: 58-65.

http://dx.doi.org/10.4021/cr24e

4. Bruin JE, Gerstein HC, Holloway AC. Long-term consequences of fetal and neonatal nicotine exposure: a critical review. Toxicol Sci 2007; 116: 364-74.

http://dx.doi.org/10.1093/toxsci/kfq103

5. Chiolero A, Faeh D, Paccaud F, Cornuz J. Consequences of smoking for body weight, body fat distribution, and insulin resistance. Am J Clin Nutr 2008; 87: 801-9.

6. Charlton A. Medicinal uses of tobacco in history. J R Soc Med 2004; 97: 292-6.

http://dx.doi.org/10.1258/jrsm.97.6.292

7. Cryer P. Haymond M. Santiago J. Shah S. Norepinephrine and epinephrine release and adrenergic mediation of smoking-associated hemodynanic events. N Eng J Med 1976; 295: 2737.

http://dx.doi.org/10.1056/NEJM197609092951101

8. Narkiewicz K, van de Borne PJ, Hausberg M et al. Cigarette smoking increases sympathetic outflow in humans. Circulation 1998; 98: 528-34. http://dx.doi.org/10.1161/01.CIR.98.6.528
9. Ciftci O, Caliskan M, Gullu $\mathrm{H}$ et al. Acute Effects of Smoking Light Cigarettes on Coronary Microvascular Functions. Clin Cardiol 2009; 32: 210-4.

http://dx.doi.org/10.1002/clc.20343

10. Minami J, Ishimitsu $T$, Matsuoka $H$. Effects of smoking cessation on blood pressure and heart rate variability in habitual smokers. Hypertension 1999; 33: 586-90.

http://dx.doi.org/10.1161/01.HYP.33.1.586

11. Yarlioglues M, Kaya MG, Ardic I et al. Acute effects of passive smoking on blood pressure and heart rate in healthy females. Blood Press Monit. 2010; 15:251-62011;

12. Pickering TG. The effects of smoking and nicotine replacement therapy on blood pressure. J Clin Hypertension 2001; 3: 319-21. http://dx.doi.org/10.1111/j.1524-6175.2001.00483.x

13. Middlekauff HR, Park J, Moheimani RS. Adverse effects of cigarette and noncigarette smoke exposure on the autonomic nervous system: mechanisms and implications for cardiovascular risk. J Am Coll Cardiol 2014; 64: 1740-50. http://dx.doi.org/10.1016/j.jacc.2014.06.1201

14. Mahmud A, Feely J. Effects of passive smoking on blood pressure and aortic pressure waveform in healthy young adults-influence of gender. British J Clin Pharm 2004; 57: 37-43. http://dx.doi.org/10.1046/j.1365-2125.2003.01958.x

15. Vlachopoulos C, Aznaouridis C, Bratsas A et al. Arterial stiffening and systemic endothelial activation induced by smoking. The role of COX-1 and COX-2. Int J Cardiol 2015; 189: 293-8. http://dx.doi.org/10.1016/j.ijcard.2015.04.029 


\title{
Akutni efekti pušenja na srčanu frekvenciju i periferni otpor kod mladih osoba
}

\author{
Ana Mrkaić1, Suzana Branković, Pavle Ranđelović1, Milica Veljković1, Ivan Pavlović2, Mirjana Radenković ${ }^{1}$ \\ ${ }^{1}$ Univerzitet u Nišu, Medicinski fakultet, Departman za fiziologiju, Niš, Srbija \\ ${ }^{2}$ Univerzitet u Beogradu, Farmaceutski fakultet, Departman za farmakognoziju, Beograd, Srbija
}

\section{SAŽETAK}

Pušenje ima mnogo štetnih efekata na ljudski organizam. Dobro je poznato da pušenje predstavlja jedan od najvažnijih faktora rizika za pojavu kardiovaskularnih bolesti. Sastojci dima cigarete stimulišu oslobađanje vazokonstriktivnih, a inhibišu oslobađanje vazodilatatornih supstanci. Zato smo kao cilj našeg rada postavili praćenje akutnih efekata pušenja cigareta na arterijski krvni peitisak, srčanu frekvenciju i periferni protok.

Istraživanje je vršeno na grupi nepušača (kontrolna grupa) i grupi pušača (eksperimentalna grupa). Klasičnim metodama su registrovani krvni pritisak i elektrokardiogram (EKG) kod nepušača, kao i kod pušača pre i nakon pušenja četiri cigarete u vremenskom razmaku od jednog sata. Periferna cirkulacija je procenjivana upotrebom pletizmografske metode Brecht and Boucke.

Naši rezultati pokazuju da nije bilo razlika u vrednostima sistolnog i dijastolnog krvnog pritiska, kao ni u EKG nalazima između nepušača i pušača. Pomenuti parametri ostaju slični i kod pušača nakon pušenja. Međutim, srčana frekvencija se nakon pušenja značajno povećava, čak za jednu trećinu $(29,57 \%)$, u poređenju sa vrednostima pre pušenja.

Procena pletizmograma pokazuje da se njegova amplituda smanjuje, a da se vrednosti parametara koji ukazuju na periferni otpor značajno povećavaju. Rastegljivost krvnih sudova (širina i površina pletizmograma) se smanjuje za oko $20 \%$, što ukazuje na smanjenje srednje vrednosti dijametra krvnih sudova.

Može se zaključiti da pušenje nema značajne akutne efekte na krvni pritisak, iako povećava srčanu frekvenciju. Pletizmogramski nalaz ukazuje na smanjenje sistolnog volumena i dijametra krvnih sudova.

Ključne reči: pušenje, srčana frekvencija, EKG, pletizmogram 